\title{
Sexual Violence and Associated Factors Among Female Students at Debre Berhan University, Ethiopia
}

\author{
Semira Mehammed Hassen ${ }^{1}$, Bedru Hussen Mohammed ${ }^{2}$ \\ 1. Obstetrics and Gynecology, School of Nursing, The University of Hong Kong, Hong Kong, HKG 2. Epidemiology and \\ Public Health, School of Public Health, The University of Hong Kong, Hong Kong, HKG
}

Corresponding author: Bedru Hussen Mohammed, bedredin4444@yahoo.com

\section{Abstract \\ Background and objective}

Sexual violence is a common and serious public health issue affecting millions of women at all stages of their lives. Studies have shown that women in Ethiopia are among the highly affected. There is no study in the literature as yet on the prevalence and factors associated with sexual violence among female students of Debre Berhan University (DBU), Ethiopia. In light of this, this study aimed to assess the prevalence of sexual violence and associated factors among female students at DBU.

\section{Methods}

A Cross-sectional institution-based study was conducted in May 2016 among female regular undergraduate students of DBU. Data was collected using a self-administered questionnaire. Descriptive, binary, and multivariable logistic regression analyses were carried out.

\section{Results}

A total of 627 female students completed the questionnaire (response rate: 91.5\%). The mean (SD) age of the students was 20.7 (1.65) years. More than half (54.9\%) of the students have been victims of sexual violence in their life. More than one-third (35.6\%) of the students have experienced rape, attempted rape, or sexual harassment while they are in DBU. Sexual harassment was the most common form of sexual violence ever experienced by female students (51.8\%) followed by attempted rape (12.8\%) and rape (9.8\%). More than half of the rape victims $(35,57.3 \%)$ did not share their experiences with anyone. Multiple logistic regression analyses revealed that Khat-chewing habit and marital status were significantly associated with rape.

\section{Conclusion}

Sexual violence, in general, is high among female students at DBU. Most of the sexual violence occurs outside of the campus and the perpetrators are mostly known to the victims and are trusted and loved by them. Further broad and longitudinal studies are needed to determine the predictors of the

Review began 04/23/2021 Review ended 06/26/2021 Published 07/05/2021

\section{(c) Copyright 2021}

Hassen et al. This is an open access article distributed under the terms of the Creative Commons Attribution License CC-BY 4.0., which permits unrestricted use, distribution, and reproduction in any medium, provided the original author and source are credited.
Categories: Preventive Medicine, Public Health, Epidemiology/Public Health

Keywords: sexual violence, female students, debre berhan university, ethiopia

\section{Introduction}

Violence against women and girls is a global issue and one of the most prevalent human rights violations; it entails denying women their right to enjoy fundamental freedom, dignity, equality, self-worth, and security. Women at any stage in their lives can be affected and it can occur in various forms, which may involve physical, psychological, sexual, social, and economic abuse. Violence against women has a huge impact on every aspect of women's lives, from their personal health, their psychological health, and self-worth to the safety of their families, and even their ability to earn a living. It is also associated with an increased risk of sexual and reproductive health issues, with both immediate and long-term consequences [1].

Sexual violence is the most widespread form of violence against women [1]. The World Health Organization (WHO) has defined it as any sexual act, attempt to obtain a sexual act, unwanted sexual comments or advances, or acts to traffic, or otherwise directed, against a person's sexuality using force, by any person regardless of their relationship to the victim, in any setting, including but not limited to home and work [1]. It is the most persistent yet underestimated social and health problem that occurs in pandemic proportions [2], and various studies have shown that women less than 25 years of age are the most common victims of sexual violence $[1,2]$. 
The WHO multi-country study on women's health and domestic violence against women in 2004 documented the result of data from 10 countries ( 15 sites), including Ethiopia. The high rates of genderbased violence documented by the study (as high as 62\%) experienced by girls and women were of great concern [3]. The prevalence of sexual violence is generally high in Africa and ranges from 16\% in Cameroun, $23 \%$ in Sierra Leone, $34.4 \%$ in Ethiopia, and $49 \%$ in Ghana to $65.6 \%$ in Zimbabwe and 67\% in Botswana [2-9].

Studies indicate that schools and universities are places where sexual violence rampantly and routinely occurs [1,2]. In Ethiopia, many studies have indicated a high prevalence of gender-based violence in general and sexual violence in particular at educational institutions. A 2008 national study conducted among a large sample of students reported that about a quarter of schoolgirls have been sexually attacked by either students or teachers [10]. In a cross-sectional survey conducted among female students at the Addis Ababa University in 2004, the lifetime prevalence of completed and attempted rape was $12.7 \%$ and $27.5 \%$, respectively, whereas $58 \%$ of the students reported experiencing lifetime sexual harassment in some form [11]. A similar study conducted among female students of Haromaya University showed that $3 \%$ of females experienced rape in their lifetime and $27.8 \%$ of students experienced uninvited sexual overtures such as verbal jokes and direct solicitation for sexual intercourse, and 19.3\% encountered unwelcome touches on their bodies [12].

Mostly, sexual violence is rarely reported worldwide [13]. Victims usually prefer to keep their painful experiences to themselves. The reasons for this could be indecision, inability to verbalize their problems in the open, fear of the attacker, or the fear that they could be asked to appear as a witness in a trial to validate their accounts. Data on sexual violence are usually gathered from clinical settings, the police, surveys, and nongovernmental organizations. Therefore, the global magnitude of the problem is thought to be higher than reported, and hence sexual violence has been called a "silent epidemic" [13-15].

Though they are not fully investigated, several of the available studies show that there is no single factor to fully account for violence perpetrated against women. There are several factors that increase the risk of someone being coerced into sex. Generally, violence against women is the result of a complex interplay of individual, relationship-related, social, cultural, and environmental factors $[1,16,17]$.

Studies have shown that sexual violence against women leads to a number of problems including unwanted pregnancy, increased risk of HIV/AIDS infection and other sexually transmitted infections (STIs), gynecological problems, feeling of worthlessness, depression, fear and guilty feeling about sex, powerlessness, shame, difficulty in trusting people, post-traumatic stress disorder (PTSD), and even suicide [5,7,16-20]. On top of that, it also exposes girls and women in schools to social consequences ranging from poor educational achievement to social withdrawal, having multiple partners, rejecting friends, drug and alcohol abuse, and even prostitution [15,17,21].

Scarce literature is available on the nature and extent of sexual violence against female students in colleges and universities in Ethiopia. Even though previous studies indicate that schools and universities are highly susceptible to sexual and gender-based violence, the problem has not been adequately addressed in the educational sector [3-5,7,8,10-12,19,22-25]. Female students in higher institutions are vulnerable to sexual violence due to various reasons in Ethiopia. High school graduates usually have to travel far away from their home and family for the first time in their lives. Gathering data concerning sexual violence among female students is vital in determining the magnitude of sexual violence and the factors associated with it. To the best of our knowledge, studies related to sexual violence have not been conducted at Debre Berhan University (DBU). This lack of reliable data on the prevalence of sexual violence and associated factors among female students at DBU drove us to undertake this study. The study provides insights that would be helpful in designing and implementing evidence-based interventions at the institutional level, and regional as well as national level programs to create a conducive environment for female students, especially in teaching-learning institutional settings.

\section{Materials And Methods}

\section{Study design and setting}

An institution-based cross-sectional study was conducted in May 2016 to assess the level of sexual violence and identify the associated factors among female students registered at DBU located in the Amhara Region, North Shoa Zone, $130 \mathrm{~km}$ North of Addis Ababa, Ethiopia.

\section{Sample size and sampling technique}

The sample size for the study was determined by using the single population proportion formula [26], based on the $41.8 \%$ prevalence of sexual violence from a study conducted among female students at the Addis Ababa University [11]. A 5\% margin of error and 95\% level of confidence were assumed. Based on these assumptions, the calculated sample size was 374 . As per the sampling technique, we used a correction formula, and a $10 \%$ of non-response rate was added, and a design effect of 1.5 was used, which gave us a final sample size of 570 female students. 
The study used a multistage sampling technique. The number of female students registered full-time in the undergraduate programs for the 2015/16 academic year in each department was obtained from the registrar and stratified based on year of study from the first up to the fifth year. After proportional allocation to each year, a cluster sampling method was employed where each department was considered as a cluster. A simple random sampling technique was used for the selection of departments; after that, all female students in the randomly selected departments were included as study subjects.

\section{Study variables and operational definitions}

Sexual violence (rape, attempted rape, and sexual harassment) was the dependent variable of the study. The independent variables of the study were sociodemographic characteristics (age, residence, religion, relationship status), substance use (cigarette, alcohol, Khat, drugs), family background (income, educational status), year of study, grade, and current living situation. The questions were divided into four sections: (i) sociodemographic characteristics of participants, (ii) substance use among participants, (iii) reproductive history of the participants, and (iv) sexual violence experience of participants. The study used the following operational definition of terms:

Rape: an act of non-consensual sexual intercourse. This can include the invasion of any part of the body with a sexual organ and/or the invasion of the genital or anal opening with any object or body part.

Attempted rape: efforts to rape someone that do not result in penetration.

Sexual harassment: unwanted sexual behavior such as physical contact or verbal comments, jokes, questions, kissing, hugging, and suggestions of sexual nature.

Sexual violence: acts of rape, attempted rape, and/or sexual harassment.

\section{Data collection}

The data was collected using a structured, pre-tested self-administered questionnaire adapted from the WHO multi-country questionnaire on violence against women [1].

Sensitive questions such as rape experience were placed later in the questionnaire in order to reduce discomfort and minimize the non-response rate. The questionnaire was translated into Amharic language and back-translated into English to check its consistency and accuracy. The questionnaire was pretested on 23 female students. The result of the pretest was discussed, and relevant changes and corrections were made in the questionnaire as necessary. Five graduating-class midwifery students carried out the data collection with close follow-up by supervisors.

The questionnaire was distributed after gathering study participants in lecture rooms or dormitories. Immediately after the distribution of the questionnaire, an orientation session was conducted to help the students understand the questions well and fill in the questionnaire, and students were asked not to write their names anywhere on the questionnaire. Finally, the students dropped their completed questionnaires into a sealed box placed at the entrance as they left. Students who had no classes during data collection filled in the questionnaire in their dormitories. The questionnaires were later checked for completeness by the investigators.

\section{Statistical analysis}

Investigators entered the data into a Microsoft Excel spreadsheet. After the entry, sprucing up and editing were carried out. It was then exported into the IBM SPSS Statistics software version 24 (IBM, Armonk, NY) and analyzed. Descriptive statistics such as means for continuous and proportions for categorical variables including cross-tabulations were used for data summarization. Differences in proportions were compared for significance using the Chi-square test, with a significance level set at $p<0.05$. When the assumptions of the Chi-square test were not fulfilled, we used Fisher's exact test.

Finally, binary and multivariate logistic regression analyses were used to identify factors associated with sexual violence by controlling for the effect of potential confounding variables. Only those variables with a p-value of less than 0.05 were included in the multivariate logistic regression analysis. Crude and adjusted odds ratio with $95 \%$ confidence intervals were used to observe the relative effect of independent variables against the dependent variable. Variables having a p-value of less than 0.05 were considered as predictors of sexual violence.

\section{Results}

Among a total of 685 students approached, 627 female students participated in the study and filled in the questionnaire (response rate: $91.5 \%)$. Of the total 627 students, $28.5 \%(n=179)$ were in their first year, $32.1 \%(n=201)$ in the second year, 18.0\% $(n=113)$ in the third year, $8.6 \%(n=54)$ in the fourth year, and $12.8 \%$ $(n=80)$ were in the fifth year. The mean age of the participants was 20.7 years $(S D=1.65$; minimum: 18 , 


\section{Cureus}

maximum: 29). Regarding religion, most of the participants $(84.8 \%, \mathrm{n}=532)$ were Orthodox Christians, followed by Protestants and Muslims: $8.0 \%(n=50)$ and $6.7 \%(n=42)$ respectively. Majority of the students were single $(61.7 \%, n=387)$, while $34.0 \%(n=213)$ were in a non-marital relationship and $3.7 \%(n=23)$ were married.

More than half $(53 \%, \mathrm{n}=332)$ of the participants' place of childhood residence was urban, and that of $47 \%$ $(n=295)$ was rural. The majority of the students $(55.3 \%, n=347)$ currently lived on campus and were non-cafe (did not use the campus mass food), followed by those living on campus and using the cafe (43.5\%, n=273), and those living outside the campus $(1.11 \%, \mathrm{n}=7)$. Among the total participants, 118 (18.8\%), 13 (2.1\%), 15 (2.4\%), and 14 (2.2\%) reported that they drank alcohol, smoked cigarettes, chewed Khat, and used drugs, respectively.

The majority of the respondents had illiterate parents: fathers $33.7 \%(n=211)$ and mothers $41.5 \%(n=260)$; followed by those with primary school and college graduate education for fathers $(25.2 \%, n=158)$, and only primary school for mothers $(23.9 \%, \mathrm{n}=150)$ (Table 1$)$.

\begin{tabular}{|c|c|c|}
\hline Variable & Variable category & N (\%) \\
\hline \multirow[t]{2}{*}{ Age in years } & $18-20$ & $335(53.4)$ \\
\hline & $21-29$ & $292(46.6)$ \\
\hline \multirow[t]{4}{*}{ Relationship status } & Single & $387(61.7)$ \\
\hline & In a relationship but not married & $213(34.0)$ \\
\hline & Married & $23(3.7)$ \\
\hline & Previously married & $4(0.6)$ \\
\hline \multirow[t]{4}{*}{ Religion } & Orthodox Christian & $532(84.8)$ \\
\hline & Muslim & $42(6.7)$ \\
\hline & Protestant Christian & $50(8.0)$ \\
\hline & Other & $3(0.5)$ \\
\hline \multirow[t]{5}{*}{ Year of study } & One & $179(28.5)$ \\
\hline & Two & $201(32.1)$ \\
\hline & Three & $113(18.0)$ \\
\hline & Four & $54(8.6)$ \\
\hline & Five & $80(12.8)$ \\
\hline \multirow[t]{2}{*}{ Cumulative GPA } & $\leq 2.80$ & $256(48.8)$ \\
\hline & $>2.80$ & $269(51.2)$ \\
\hline \multirow[t]{2}{*}{ Place of childhood residence } & Rural area & $295(47.0)$ \\
\hline & Urban area & $332(53.0)$ \\
\hline \multirow[t]{3}{*}{ Current living condition } & On campus and using café & $273(43.5)$ \\
\hline & On campus but non-cafe & $347(55.3)$ \\
\hline & Outside campus & $7(1.2)$ \\
\hline \multirow[t]{2}{*}{ Parents' monthly income } & $\leq 3,000$ Birr & $145(50.2)$ \\
\hline & $>3,000$ Birr & $144(49.8)$ \\
\hline \multirow[t]{4}{*}{ Father's educational status } & Illiterate & $211(33.7)$ \\
\hline & Primary school & $158(25.2)$ \\
\hline & High school & $100(15.9)$ \\
\hline & College graduate & $158(25.2)$ \\
\hline Mother's educational status & Illiterate & $260(41.5)$ \\
\hline
\end{tabular}




\section{Cureus}

\begin{tabular}{|c|c|c|}
\hline & Primary school & $150(23.9)$ \\
\hline & High school & $115(18.3)$ \\
\hline & College graduate & 102 (16.3) \\
\hline \multirow[t]{2}{*}{ Cigarette smoking } & No & $614(97.9)$ \\
\hline & Yes & $13(2.1)$ \\
\hline \multirow[t]{2}{*}{ Alcohol consumption } & No & $509(81.2)$ \\
\hline & Yes & $118(18.8)$ \\
\hline \multirow[t]{2}{*}{ Chewing Khat } & No & $612(97.6)$ \\
\hline & Yes & $15(2.4)$ \\
\hline \multirow[t]{2}{*}{ Using drugs (cocaine, shisha, or marijuana) } & No & $613(97.8)$ \\
\hline & Yes & $14(2.2)$ \\
\hline Total & & $627(100)$ \\
\hline
\end{tabular}

TABLE 1: Sociodemographic characteristics of female students of DBU, May 2016

DBU: Debre Berhan University; GPA: grade point average

\section{Sexual experience}

Only 128 (20.4\%) of the students reported having sexual intercourse previously. The mean age of female students at their first sexual intercourse had been 18.1 years $(\mathrm{SD}=2.92$; minimum: seven years, maximum: 24 years). Of those who had already had sexual intercourse, 15 (11.8\%) had three or more sexual partners. The most common reason for starting sexual intercourse was personal desire (36, 28.1\%); followed by the partner's promising words $(35,27.3 \%)$, marriage $(30,23.4 \%)$, and use of force by the perpetrator $(13,10.2 \%)$ (Table 2). 


\section{Cureus}

Variable

Variable category

N (\%)

Ever had sexual intercourse

Yes

No

Number of sexual partners

$$
\text { One }
$$

Two

20 (16.6)

Three

Four or more

8 (6.2)

Reason for starting sexual intercourse

Marriage

Personal desire

$36(28.1)$

Promising words from partner

35 (27.3)

Forced

Peer pressure

Other

Total

$627(100)$

TABLE 2: Sexual experience among female students of DBU, May 2016

DBU: Debre Berhan University

\section{Sexual violence experience}

More than half $(54.9 \%, n=345)$ of the students had been a victim of at least one of the three sexual violence types in their life. More than one in three $(35.6 \%, \mathrm{n}=224)$ of the students had been victims of rape, attempted rape, or sexual harassment while they were in DBU. Out of the total 627, 61 (9.8\%) and 10 (1.6\%) students had been victims of completed rape in their life and in DBU respectively. More than one in four of the victims of completed rape had experienced it more than once.

Sexual harassment was the most common type of sexual violence ever encountered by female students, as reported by $51.8 \%(n=325)$ of participants, followed by attempted rape $(12.8 \%, n=80)$, and rape $(9.8 \%, n=61)$. Most of the victims of rape had been raped once (7.2\%), twice (1.8\%), and three or more times (0.8\%). Of the students who had experienced sexual intercourse, $47.6 \%(n=61)$ had been raped at least once in their lifetime (Figure 1$)$. In addition, $13 \%(\mathrm{n}=82)$ of students reported knowing a female student who had been raped in DBU. 


\section{Cureus}

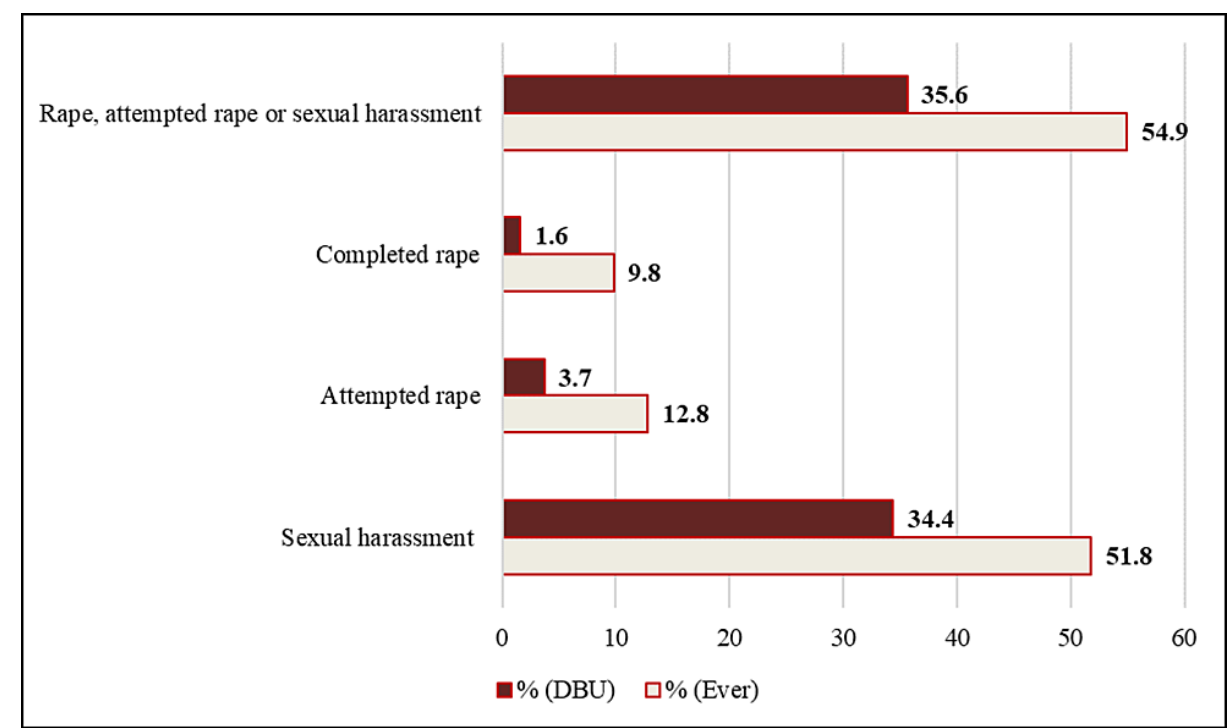

FIGURE 1: The proportion of different types of sexual violence experience ever and in DBU among female students of DBU, May 2016

DBU: Debre Berhan University

More than one in three female students (34.4\%) had been a victim of sexual harassment while they were in DBU. Unwanted verbal jokes of sexual nature or requests to have sex were the most common types of sexual harassment experienced by the participants ever (39.2\%) and in DBU (25\%) (Figure 2).

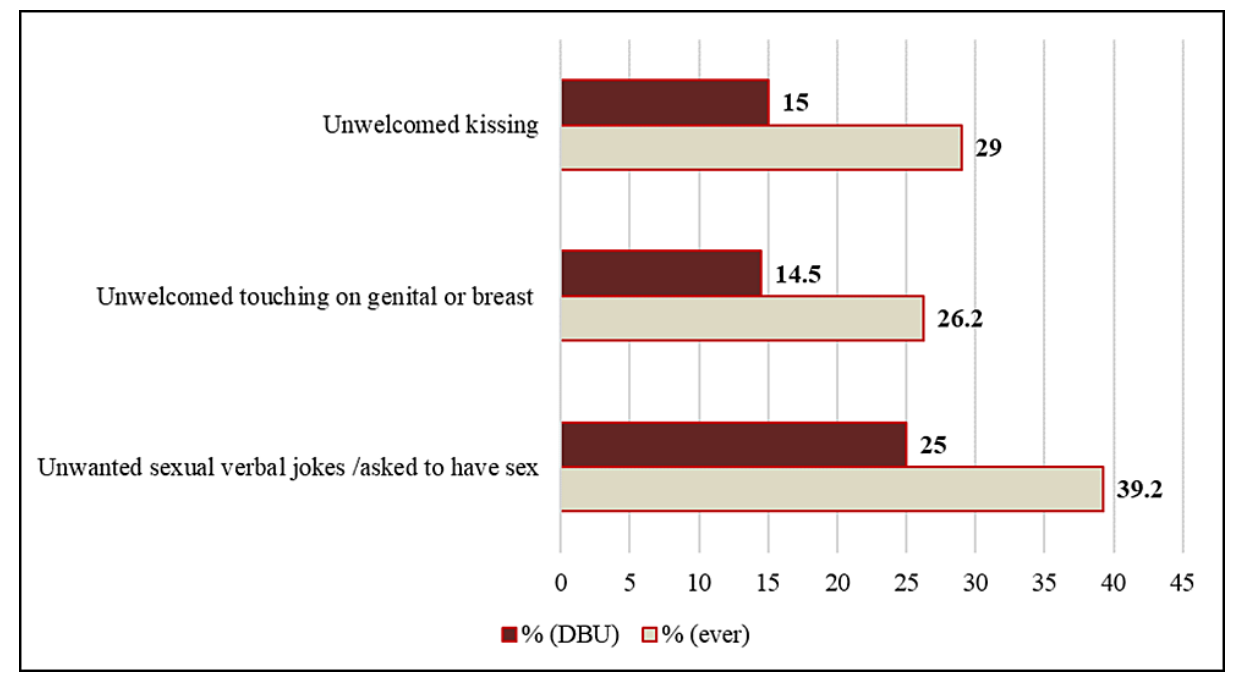

FIGURE 2: The proportion of different types of sexual harassment experienced ever and in DBU among female students of DBU, May 2016

DBU: Debre Berhan University

Fellow students were the most common (73.5\%) perpetrators of sexual violence in DBU against female students, followed by teachers (17.9\%) (Figure 3). However, boyfriends (27.9\%) and close relatives (26.2\%) were the most common perpetrators of sexual violence in students' lifetimes (Figure 4). 


\section{Cureus}

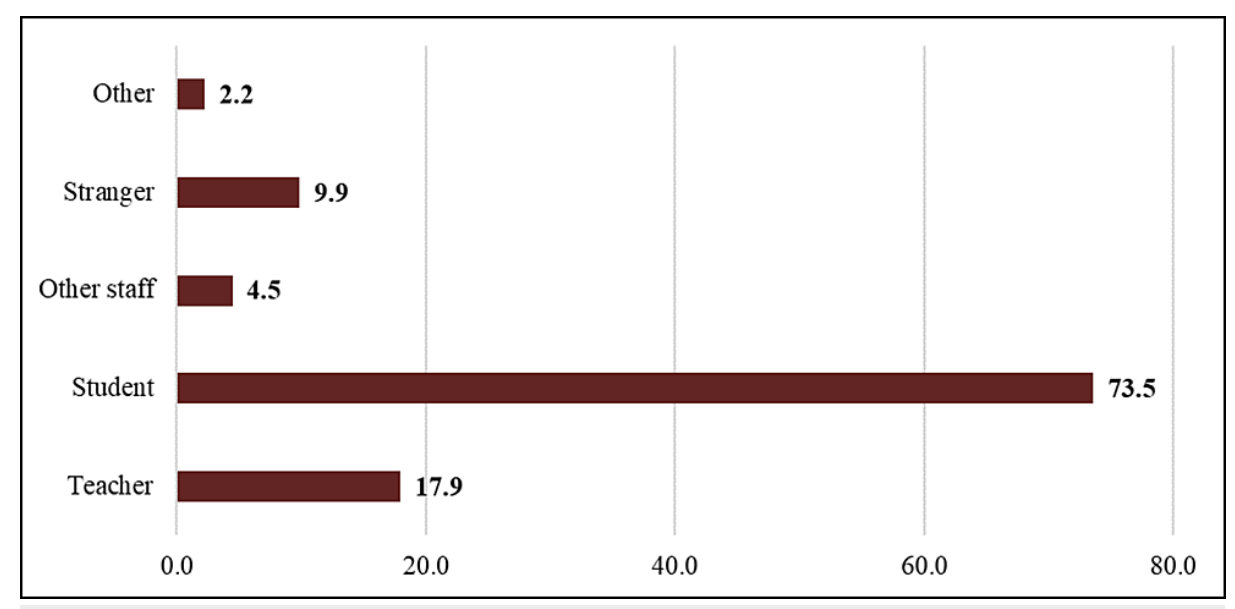

FIGURE 3: Perpetrators of sexual violence in DBU among female students of DBU, May 2016

DBU: Debre Berhan University

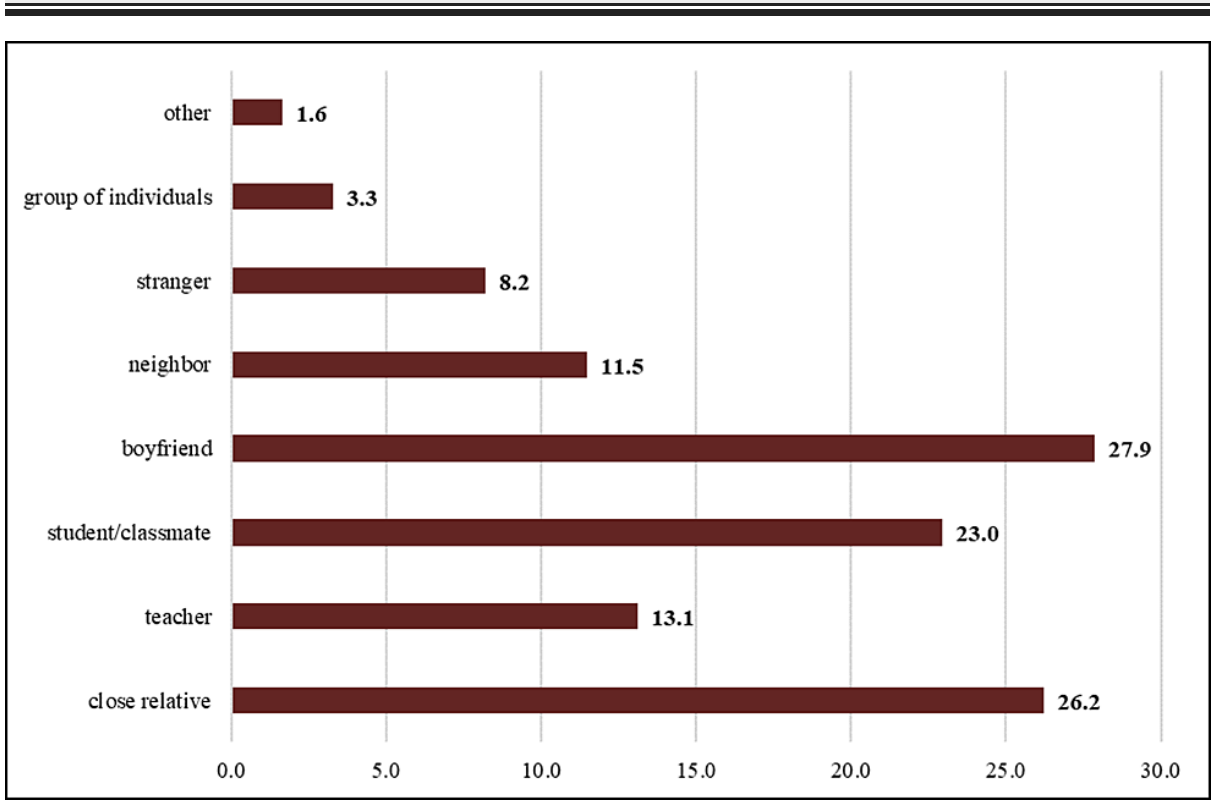

FIGURE 4: Lifetime perpetrators of sexual violence among female regular students of DBU, May 2016*

*Multiple responses were possible for one query, and hence the cumulative percentage may exceed $100 \%$

DBU: Debre Berhan University

Similarly, the mechanisms used to force the victims into sex are different. More than a quarter of victims were forced by hitting or biting; $23.6 \%$ ( $n=13)$ were violated by making them drunk or intoxicated; and $10.9 \%$ $(\mathrm{n}=6)$ were lured into sexual acts by promising them to award more marks or grades. The majority of the perpetrators $(65.4 \%, \mathrm{n}=46)$ were older than the victims. Most of the completed rapes $(36.1 \%, \mathrm{n}=22)$ happened in the victims' house, while $19.7 \%(\mathrm{n}=12)$ took place in the perpetrators' house, $18 \%(\mathrm{n}=11)$ in hotels, $16.4 \%$ $(n=10)$ in schools, $13.1 \%(n=8)$ in friends' houses, and $4.9 \%(n=3)$ in the university campus.

\section{Reporting of sexual violence}

More than half of the victims of sexual violence $(57.3 \%, \mathrm{n}=35)$ did not share the experience with anyone. However, 27.8\% $(n=17)$ of the victims shared their situation with friends and $13.1 \%(n=8)$ shared it with their families. Most of the victims $(98.3 \%, \mathrm{n}=60)$ did not report to the legal authorities. Out of those who did not share with anyone or to the legal bodies, the main reasons cited were that they did not know what to do $(45.7 \%, \mathrm{n}=16)$, fear of shame $(40 \%, \mathrm{n}=14)$, fear of parents' response $(31.4 \%, \mathrm{n}=11)$, and fear of perpetrators 


\section{Cureus}

$(22.8 \%, \mathrm{n}=8)$

\section{Attitude towards sexual violence}

The majority of the participants $(35.7 \%, \mathrm{n}=224)$ said that they would confide in their health professionals, $28.5 \%(n=179)$ said they would report to the police or legal authorities, $20.1 \%(n=126)$ to a friend, $19.8 \%$ $(n=124)$ to a family member, and $10 \%(n=63)$ said that they would not tell anyone (Figure 5).

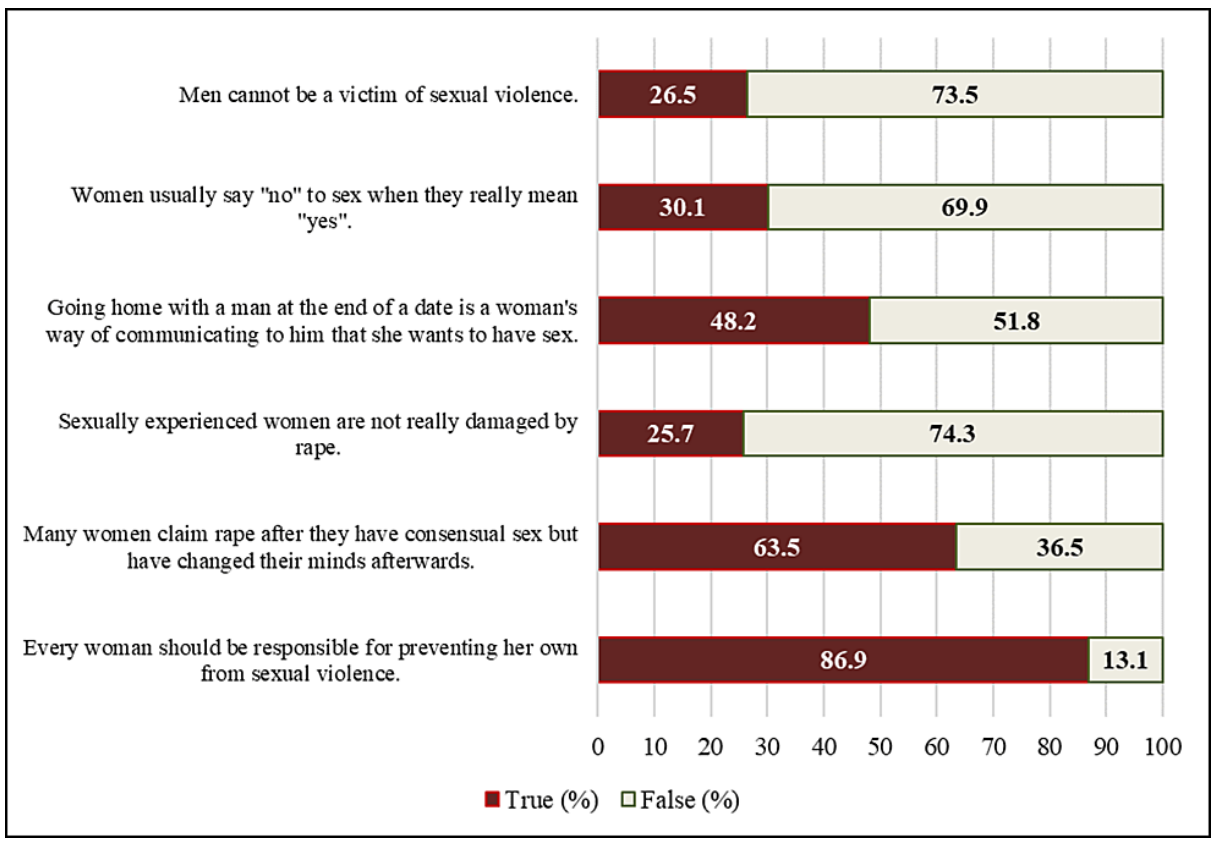

FIGURE 5: Attitude towards sexual violence among female students of DBU, May 2016

DBU: Debre Berhan University

\section{Predictors of sexual violence}

Table 3 depicts the predictors of sexual violence among female students in DBU. On bivariate analysis, rape was significantly associated with substance (drug and Khat) use, cigarette smoking, parents' educational status, year of study, and relationship status. However, after controlling for all covariates, the multivariate logistic regression result showed that only relationship status, study year, and chewing Khat were significantly associated with rape. Students who reported to be in a relationship but not married, currently married, and previously married were more likely to have been raped than students who reported to being single: adjusted odds ratio (AOR) $=5.21$ (95\% CI=1.51-18.04), AOR=27.03 (95\% CI=3.96-184.5), AOR=131.9 (95\% CI=3.36-5170) respectively (Table 3). Students who were in years two and four were less likely to report rape than year-one students: $\mathrm{AOR}=0.08(95 \% \mathrm{CI}=0.01-0.52)$ and $\mathrm{AOR}=0.05(95 \% \mathrm{CI}=0.003-0.87)$ respectively. Students who reported having a habit of chewing Khat were found to be 16.7 times more at risk of being a rape victim: AOR=16.7 (95\% CI=1.24-227.3).

\begin{tabular}{|c|c|c|c|c|c|c|c|c|}
\hline \multirow{2}{*}{ Variable } & \multicolumn{2}{|l|}{ Rape } & \multicolumn{2}{|c|}{ Attempted rape } & \multicolumn{2}{|c|}{ Sexual harassment } & \multicolumn{2}{|c|}{$\begin{array}{l}\text { Any of the sexual } \\
\text { violence acts* }\end{array}$} \\
\hline & $\begin{array}{l}\text { COR }(95 \% \\
\mathrm{Cl})\end{array}$ & $\begin{array}{l}\text { AOR }(95 \% \\
\mathrm{Cl})\end{array}$ & $\begin{array}{l}\text { COR }(95 \% \\
\mathrm{Cl})\end{array}$ & $\begin{array}{l}\text { AOR }(95 \% \\
\mathrm{Cl})\end{array}$ & $\begin{array}{l}\text { COR }(95 \% \\
\mathrm{Cl})\end{array}$ & $\begin{array}{l}\text { AOR }(95 \% \\
\mathrm{Cl})\end{array}$ & $\begin{array}{l}\text { COR }(95 \% \\
\mathrm{Cl})\end{array}$ & $\begin{array}{l}\text { AOR }(95 \% \\
\mathrm{Cl})\end{array}$ \\
\hline \multicolumn{9}{|c|}{ Age in years } \\
\hline $18-20$ & 1 & 1 & 1 & & 1 & 1 & 1 & 1 \\
\hline 21-29 & $\begin{array}{l}1.50(0.88- \\
2.56)\end{array}$ & $\begin{array}{l}1.53(0.38- \\
6.11)\end{array}$ & $\begin{array}{l}1.10(0.69- \\
1.76)\end{array}$ & & $\begin{array}{l}1.38(1.01- \\
1.89)^{\star \star}\end{array}$ & $\begin{array}{l}1.80(0.91- \\
3.58)\end{array}$ & $\begin{array}{l}1.39(1.02- \\
1.91)\end{array}$ & $\begin{array}{l}1.72(0.86- \\
3.42)\end{array}$ \\
\hline \multicolumn{9}{|c|}{ Relationship status } \\
\hline Single & 1 & 1 & 1 & 1 & 1 & 1 & 1 & 1 \\
\hline
\end{tabular}




\begin{tabular}{|c|c|c|c|c|c|c|c|c|}
\hline $\begin{array}{l}\text { In a relationship but } \\
\text { not married }\end{array}$ & $\begin{array}{l}3.55(1.96- \\
6.42)\end{array}$ & $\begin{array}{l}5.21(1.51- \\
18.04)\end{array}$ & $\begin{array}{l}1.88(1.16- \\
3.04)\end{array}$ & $\begin{array}{l}2.54(1.06- \\
6.01)\end{array}$ & $\begin{array}{l}1.83(1.30- \\
2.58)\end{array}$ & $\begin{array}{l}1.67(0.92- \\
3.04)\end{array}$ & $\begin{array}{l}2.18(1.54- \\
3.09)\end{array}$ & $\begin{array}{l}1.84(1.004- \\
3.38)\end{array}$ \\
\hline Married & $\begin{array}{l}10.3(3.90- \\
27.4)\end{array}$ & $\begin{array}{l}27.03(3.96- \\
184.5)\end{array}$ & $\begin{array}{l}0.82(0.18- \\
3.65)\end{array}$ & $\begin{array}{l}1.03(0.14- \\
7.83)\end{array}$ & $\begin{array}{l}1.05(0.45- \\
2.44)\end{array}$ & $\begin{array}{l}0.65(0.18- \\
2.34)\end{array}$ & $\begin{array}{l}1.69(0.72- \\
4.02)\end{array}$ & $\begin{array}{l}1.11(0.31- \\
3.98)\end{array}$ \\
\hline Previously married & $\begin{array}{l}6.46(0.64- \\
65.0)\end{array}$ & $\begin{array}{l}131.9(3.36- \\
5170)\end{array}$ & 0.000 & 0.000 & $\begin{array}{l}3.45(0.35- \\
33.4)\end{array}$ & $\begin{array}{l}4.00(0.25- \\
62.25)\end{array}$ & $\begin{array}{l}3.27(0.34- \\
31.7)\end{array}$ & $\begin{array}{l}2.38(0.16- \\
33.8)\end{array}$ \\
\hline \multicolumn{9}{|l|}{ Year of study } \\
\hline One & 1 & 1 & 1 & 1 & 1 & 1 & 1 & 1 \\
\hline Two & $\begin{array}{l}0.82(0.40- \\
1.68)\end{array}$ & $\begin{array}{l}0.080(0.01- \\
0.52)\end{array}$ & $\begin{array}{l}0.68(0.36- \\
1.27)\end{array}$ & $\begin{array}{l}0.69(0.22- \\
2.25)\end{array}$ & $\begin{array}{l}0.63(0.42- \\
0.94)\end{array}$ & $\begin{array}{l}0.28(0.13- \\
0.61)\end{array}$ & $\begin{array}{l}0.71(0.47- \\
1.06)\end{array}$ & $\begin{array}{l}0.31(0.15- \\
0.66)\end{array}$ \\
\hline Four & $\begin{array}{l}0.76(3.46- \\
2.37)\end{array}$ & $\begin{array}{l}0.05(0.003- \\
0.87)\end{array}$ & $\begin{array}{l}0.77(0.29- \\
1.98)\end{array}$ & $\begin{array}{l}0.28(0.03- \\
3.01)\end{array}$ & $\begin{array}{l}0.845(0.46- \\
1.55)\end{array}$ & $\begin{array}{l}0.33(0.11- \\
1.01)\end{array}$ & $\begin{array}{l}0.98(0.54- \\
1.82)\end{array}$ & $\begin{array}{l}0.38(0.13- \\
1.19)\end{array}$ \\
\hline Five & $\begin{array}{l}0.91(0.36- \\
2.29)\end{array}$ & $\begin{array}{l}0.31(0.03- \\
2.86)\end{array}$ & $\begin{array}{l}0.59(0.24- \\
1.42)\end{array}$ & $\begin{array}{l}0.64(0.11- \\
3.89)\end{array}$ & $\begin{array}{l}1.14(0.67- \\
1.94)\end{array}$ & $\begin{array}{l}0.44(0.14- \\
1.45)\end{array}$ & $\begin{array}{l}1.18(0.69- \\
2.02)\end{array}$ & $\begin{array}{l}0.50(0.15- \\
1.65)\end{array}$ \\
\hline \multicolumn{9}{|l|}{$\begin{array}{l}\text { Place of childhood } \\
\text { residence }\end{array}$} \\
\hline Rural area & 1 & 1 & 1 & 1 & 1 & & 1 & \\
\hline \multicolumn{9}{|l|}{$\begin{array}{l}\text { Current living } \\
\text { condition }\end{array}$} \\
\hline $\begin{array}{l}\text { On campus but none- } \\
\text { cafe }\end{array}$ & $\begin{array}{l}0.61(0.36- \\
1.05)\end{array}$ & $\begin{array}{l}0.35(0.09- \\
1.24)\end{array}$ & $\begin{array}{l}0.48(0.30- \\
0.79)\end{array}$ & $\begin{array}{l}0.42(0.15- \\
1.09)\end{array}$ & $\begin{array}{l}1.35(0.98- \\
1.85)\end{array}$ & $\begin{array}{l}1.21(0.63- \\
2.32)\end{array}$ & $\begin{array}{l}1.31(0.95- \\
1.80)\end{array}$ & $\begin{array}{l}1.05(0.55- \\
2.02)\end{array}$ \\
\hline Outside the campus & $\begin{array}{l}1.21(0.14- \\
10.3)\end{array}$ & $\begin{array}{l}0.60(0.01- \\
53.02)\end{array}$ & $\begin{array}{l}0.80(0.09- \\
6.81)\end{array}$ & 0.000 & $\begin{array}{l}1.47(0.32- \\
6.67)\end{array}$ & $\begin{array}{l}0.93(0.09- \\
9.42)\end{array}$ & $\begin{array}{l}2.41(0.46- \\
12.6)\end{array}$ & $\begin{array}{l}2.61(0.19- \\
35.37)\end{array}$ \\
\hline \multicolumn{9}{|l|}{$\begin{array}{l}\text { Father's educational } \\
\text { status }\end{array}$} \\
\hline Illiterate & 1 & 1 & 1 & 1 & 1 & 1 & 1 & 1 \\
\hline Primary school & $\begin{array}{l}0.45(0.22- \\
0.93)\end{array}$ & $\begin{array}{l}0.46(0.12- \\
1.78)\end{array}$ & $\begin{array}{l}1.18(0.67- \\
2.10)\end{array}$ & $\begin{array}{l}1.47(0.51- \\
4.33)\end{array}$ & $\begin{array}{l}1.10(0.73- \\
1.66)\end{array}$ & $\begin{array}{l}0.68(0.31- \\
1.55)\end{array}$ & $\begin{array}{l}0.97(0.64- \\
1.48)\end{array}$ & $\begin{array}{l}0.69(0.31- \\
1.56)\end{array}$ \\
\hline High school & $\begin{array}{l}0.53(0.93- \\
1.19)\end{array}$ & $\begin{array}{l}0.38(0.05- \\
3.25)\end{array}$ & $\begin{array}{l}0.82(0.40- \\
1.68)\end{array}$ & $\begin{array}{l}1.49(0.33- \\
6.74)\end{array}$ & $\begin{array}{l}0.76(0.47- \\
1.23)\end{array}$ & $\begin{array}{l}0.42(0.14- \\
1.25)\end{array}$ & $\begin{array}{l}0.69(0.43- \\
1.12)\end{array}$ & $\begin{array}{l}0.44(0.15- \\
1.31)\end{array}$ \\
\hline College graduate & $\begin{array}{l}0.49(0.25- \\
1.00)\end{array}$ & $\begin{array}{l}0.66(0.08- \\
5.04)\end{array}$ & $\begin{array}{l}0.49(0.24- \\
1.00)\end{array}$ & $\begin{array}{l}0.54(0.09- \\
3.22)\end{array}$ & $\begin{array}{l}1.28(0.85- \\
1.95)\end{array}$ & $\begin{array}{l}1.05(0.340- \\
3.25)\end{array}$ & $\begin{array}{l}1.26(0.83- \\
1.92)\end{array}$ & $\begin{array}{l}1.18(0.37- \\
3.70)\end{array}$ \\
\hline \multicolumn{9}{|l|}{$\begin{array}{l}\text { Mother's educational } \\
\text { status }\end{array}$} \\
\hline
\end{tabular}




\section{Cureus}

\begin{tabular}{|c|c|c|c|c|c|c|c|c|}
\hline \multicolumn{9}{|l|}{ income } \\
\hline$\leq 3,000$ Birr & 1 & & 1 & & 1 & 1 & 1 & 1 \\
\hline$>3,000$ Birr & $\begin{array}{l}0.80(0.37- \\
1.73)\end{array}$ & & $\begin{array}{l}0.84(0.43- \\
1.65)\end{array}$ & & $\begin{array}{l}1.42(0.89- \\
2.26)\end{array}$ & $\begin{array}{l}1.24(0.63- \\
2.43)\end{array}$ & $\begin{array}{l}1.43(0.89- \\
2.28)\end{array}$ & $\begin{array}{l}1.30(0.66- \\
2.55)\end{array}$ \\
\hline \multicolumn{9}{|l|}{ Cumulative GPA } \\
\hline$\leq 2.80$ & 1 & 1 & 1 & 1 & 1 & & 1 & \\
\hline$>2.80$ & $\begin{array}{l}0.68(0.37- \\
1.25)\end{array}$ & $\begin{array}{l}0.63(0.21- \\
1.91)\end{array}$ & $\begin{array}{l}0.64(0.38- \\
1.06)\end{array}$ & $\begin{array}{l}0.41(0.17- \\
1.00)\end{array}$ & $\begin{array}{l}1.07(0.76- \\
1.52)\end{array}$ & & $\begin{array}{l}0.98(0.69- \\
1.38)\end{array}$ & \\
\hline \multicolumn{9}{|l|}{ Cigarette smoking } \\
\hline Never & 1 & & 1 & 1 & 1 & 1 & 1 & 1 \\
\hline Smokes cigarette & $\begin{array}{l}4.34(1.29- \\
14.5)\end{array}$ & $\begin{array}{l}1.33(0.03- \\
58.63)\end{array}$ & $\begin{array}{l}4.49(1.43- \\
14.08)\end{array}$ & $\begin{array}{l}0.57(0.01- \\
31.4)\end{array}$ & $\begin{array}{l}11.54(1.49- \\
89.3)\end{array}$ & $2.65(0.000)$ & $\begin{array}{l}10.19(1.32- \\
78.9)\end{array}$ & $3.21(0.000)$ \\
\hline \multicolumn{9}{|c|}{ Alcohol consumption } \\
\hline Never & 1 & 1 & 1 & 1 & 1 & 1 & 1 & 1 \\
\hline Drink alcohol & $\begin{array}{l}1.62(0.87- \\
2.97)\end{array}$ & $\begin{array}{l}1.21(0.31- \\
4.71)\end{array}$ & $\begin{array}{l}1.78(1.04- \\
3.05)\end{array}$ & $\begin{array}{l}1.67(0.60- \\
4.66)\end{array}$ & $\begin{array}{l}2.88(1.86- \\
4.47)\end{array}$ & $\begin{array}{l}1.48(0.68- \\
3.22)\end{array}$ & $\begin{array}{l}2.75(1.76- \\
4.29)\end{array}$ & $\begin{array}{l}1.38(0.64- \\
2.99)\end{array}$ \\
\hline \multicolumn{9}{|l|}{ Chewing Khat } \\
\hline Never & 1 & 1 & 1 & 1 & 1 & & 1 & \\
\hline Chew Khat & $\begin{array}{l}9.04(3.16- \\
25.8)\end{array}$ & $\begin{array}{l}16.7(1.24- \\
227.3)\end{array}$ & $\begin{array}{l}2.56(0.79- \\
8.25)\end{array}$ & $\begin{array}{l}3.63(0.17- \\
76.11)\end{array}$ & $\begin{array}{l}1.574 \\
(0.000)\end{array}$ & & $\begin{array}{l}0.99 \\
(1.390 \text { E9-0) }\end{array}$ & \\
\hline \multicolumn{9}{|l|}{ Drug use $\mathrm{e}^{\star \star \star}$} \\
\hline Never & 1 & 1 & 1 & & 1 & 1 & 1 & 1 \\
\hline Use drugs & $\begin{array}{l}5.53(1.79- \\
17.0)\end{array}$ & $\begin{array}{l}1.80(0.10- \\
32.38)\end{array}$ & $\begin{array}{l}1.89(0.51- \\
6.95)\end{array}$ & & $\begin{array}{l}3.49(0.96- \\
12.6)\end{array}$ & $\begin{array}{l}0.18(0.01- \\
2.71)\end{array}$ & $\begin{array}{l}3.08(0.85- \\
11.16)\end{array}$ & $\begin{array}{l}0.17(0.01- \\
2.52)\end{array}$ \\
\hline
\end{tabular}

TABLE 3: Factors associated with female students' sexual violence experience: binary logistic regression analysis, May 2016

${ }^{\star}$ At least one of the three types of sexual violence; ${ }^{* \star} p$-value less than 0.05 ; ${ }^{\star \star \star}$ use of cocaine, shisha, marijuana, etc.

COR: crude odds ratio; AOR: adjusted odds ratio (adjusted for all covariates); Cl: confidence interval

Being a victim of attempted rape was significantly associated with relationship status, current living conditions, mother's educational status, cigarette smoking, and alcohol drinking in bivariate analysis. However, only the mother's educational status was found to be significantly associated with attempted rape after the multivariate analysis. Students who reported having a mom with a high school educational level were $92 \%$ less likely to have been a victim of attempted rape than students with illiterate moms ( $\mathrm{AOR}=0.08$; $95 \% \mathrm{CI}=0.01-0.88)$.

Likewise, sexual harassment was significantly associated with age, relationship status, year of study, cigarette smoking, and alcohol consumption in the bivariate analysis; however, after controlling for all covariates, only the year of study was found to be significantly associated. Year-two students were $72 \%$ less likely to report sexual harassment than year-one students ( $\mathrm{AOR}=0.28 ; 95 \% \mathrm{CI}=0.13-0.61)$.

Lastly, the occurrence of any of the three sexual violence types was significantly associated with age, relationship status, cigarette smoking, and alcohol consumption in the bivariate analysis. However, multivariate analysis results showed that relationship status and year of study were the only covariates that were significantly associated with overall sexual violence. Students who were in non-marital relationships were $84 \%$ ( $\mathrm{AOR}=1.84$; $95 \% \mathrm{CI}=1.004-3.38)$ more at risk of any of the three sexual violence types than single students. In addition, year-two students were $70 \%(\mathrm{AOR}=0.31 ; 95 \% \mathrm{CI}=0.15-0.66)$ less likely to encounter any of the three sexual violence types. 


\section{Discussion}

Out of the 627 participants, 61 (9.8\%) and 10 (1.6\%) had been victims of completed rape in their life and in DBU respectively. Sixteen (26.2\%) of the victims had been victims of completed rape more than once. This study finding is almost similar to a study conducted in Chile on the prevalence of and risk factors for sexual victimization, which revealed that $9 \%$ of rape was reported among college students [27]. A study in Addis Ababa has also revealed a close result: that the prevalence of completed rape and attempted rape was $5 \%$ and $10 \%$, respectively [11]. On the contrary, a study conducted among female students of Haramaya University reported much lower rates than this one, which was $3 \%$ lifetime rape and $19.3 \%$ sexual harassment [12]. This could be partly because the authors used only one parameter to measure sexual harassment, which is "encountered unwelcome touch on private bodies".

The findings of this study are comparable with those of a cross-sectional survey conducted among female students at the Addis Ababa University in 2004, in which the prevalence of lifetime completed and attempted rape was $12.7 \%$ and $27.5 \%$, respectively, whereas sexual harassment reported in a lifetime and 12 month period was $58 \%$ and $41.8 \%$, respectively [11].

The rape report rate that this study found in DBU (1.6\%) is almost similar to a study in South Africa, which found that in the course of a year, $1.3 \%$ of women (aged 18-49 years) had been forced, physically or by means of verbal threats, to have non-consensual sex [12]. The finding of this study is very low compared to a 2013 study in Hawassa University, which found instances of $14.3 \%$ of completed rape among students since being admitted to the university and 3\% in just the past year [28]. This could be due to reporting bias in the previous study. The finding is also similar to the finding of another study conducted among female college students in Mekelle, which reported that 34.4\% had experienced sexual violence since joining college [29].

Sexual harassment was found to be the most common form of sexual violence ever experienced by female students (51.8\%). More than one in three female students (34.4\%) have been a victim of sexual harassment while they are in DBU, which is lower than reported in a 2004 study at Addis Ababa University, which documented a sexual harassment rate of $74.3 \%$ [11]. The finding of lifetime sexual harassment was almost similar to the study in Addis Ababa, in which 58\% of students reported experiencing sexual harassment in their lifetime [11].

In a study conducted at Addis Ababa University, female students reported a similar finding in rape prevalence, $12.7 \%$ [11]. However, the same study reported a lifetime attempted rape rate of $27.5 \%$, which is very high compared to the current study. This could be due to the small sample size in the previous study. The same study reported that $58 \%$ of female students had experienced at least one form of sexual harassment in their lifetime, which is comparable to our study. This study finding was higher than a report from Haramaya University, which revealed that $3 \%$ of females experienced rape in their lifetime [12]. This could be explained by the remoteness of the latter university, which is located far from any urban area.

In this study, among the factors significantly associated with rape, relationship status, study year, and chewing Khat retained their significance even after controlling for other covariates. Multiple logistic regression analyses revealed that Khat-chewing habit and marital status were significantly associated with rape.

Mothers' educational status was the only factor significantly associated with attempted rape. Students who reported having a mom with a high school education were less likely to have been a victim of attempted rape than students with illiterate moms. This could be explained by the fact that educated moms may teach their daughters about sexual violence, which might help them protect themselves better.

Year-two students were less likely to be rape and sexual harassment victims than year-one students and were less likely to experience any of the three sexual violence types compared to year-one students. Similarly, students who were in year four were less likely to be rape victims than year-one students.

Although studies have reported that sexual violence cases often involve alcohol consumption by the perpetrator, victim, or both [30], in our study, alcohol consumption was not associated with any of the sexual violence types when controlled for other covariates. Students who were in a non-marital relationship were at a higher risk of experiencing either of the three sexual violence types than single students, even though it is not clear if being in a non-marital relationship is a cause or consequence.

This study has some limitations, including possible under-reporting of the outcome variables (especially rape) because of the sensitivity attached to the subject of sexual violence. In addition, the study could most likely have been affected by recall bias since it deals with past experiences. Hence, the findings of the study should be interpreted with caution.

\section{Conclusions}

The study revealed that the prevalence of sexual violence, in general, was high among DBU female students, 
and sexual harassment was the most common form of sexual violence ever experienced by female students followed by attempted rape and rape. Hence, parents and legal guardians of girls should be aware of the risk of sexual violence by individuals who are close to the girls and take caution to protect the girls. The university should also raise awareness among female students about sexual violence and urge them to report sexual violence; the university authorities should encourage survivors of sexual violence to seek medical care and provide information as to where to go for treatment and legal advice if they experience sexual violence of any sort. Further broad and longitudinal studies are needed to determine the predictors of the problem among female students in DBU and Ethiopia as a whole.

\section{Additional Information}

\section{Disclosures}

Human subjects: Consent was obtained or waived by all participants in this study. Animal subjects: All authors have confirmed that this study did not involve animal subjects or tissue. Conflicts of interest: In compliance with the ICMJE uniform disclosure form, all authors declare the following: Payment/services info: All authors have declared that no financial support was received from any organization for the submitted work. Financial relationships: All authors have declared that they have no financial relationships at present or within the previous three years with any organizations that might have an interest in the submitted work. Other relationships: All authors have declared that there are no other relationships or activities that could appear to have influenced the submitted work.

\section{Acknowledgements}

We would like to extend our deepest gratitude to Mr. Abdurahman Mohammed and Mr. Wassie Negash for their advice. This study would not be possible without the participants of the study; hence, we would like to extend our appreciation to them for taking the time to answer our study questionnaire.

\section{References}

1. García-Moreno C, Jansen HA, Ellsberg M, Heise L, Watts C: WHO Multi-Country Study on Women's Health and Domestic Violence against Women. WHO, Geneva, Switzerland; 2005.

2. Brown DW, Riley L, Butchart A, Meddings DR, Kann L, Harvey AP: Exposure to physical and sexual violence and adverse health behaviours in African children: results from the Global School-based Student Health Survey. Bull World Health Organ. 2009, 87:447-55. 10.2471/blt.07.047423

3. Worku A, Addisie M: Sexual violence among female high school students in Debark, north west Ethiopia . East Afr Med J. 2002, 79:96-9. 10.4314/eamj.v79i2.8911

4. Fitaw Y, Haddis K, Million F, et al.: Gender-besed violence among high school students in north west Ethiopia. Ethiop Med J. 2005, 43:215-21.

5. Worku D, Gebremariam A, Jayalakshmi S: Child sexual abuse and its outcomes among high school students in southwest Ethiopia. Trop Doct. 2006, 36:137-40. 10.1258/004947506777978325

6. Abeya SG, Afework MF, Yalew AW: Intimate partner violence against women in western Ethiopia: prevalence, patterns, and associated factors. BMC Public Health. 2011, 11:913. 10.1186/1471-2458-11-913

7. Bekele $A B$, van Aken MA, Dubas JS: Sexual violence victimization among female secondary school students in eastern Ethiopia. Violence Vict. 2011, 26:608-30. 10.1891/0886-6708.26.5.608

8. Tora A: Assessment of sexual violence against female students in Wolaita Sodo University, Southern Ethiopia. J Interpers Violence. 2013, 28:2351-67. 10.1177/0886260512475316

9. Semahegn A, Mengistie B: Domestic violence against women and associated factors in Ethiopia; systematic review. Reprod Health. 2015, 12:78. 10.1186/s12978-015-0072-1

10. Save the Children Denmark, Ministry of Education, Ministry of Women's Affairs: A Study on Violence Against Girls in Primary Schools and Its Impacts on Girls' Education in Ethiopia. 2008.

11. Tadesse S: Assessment of Sexual Coercion Among Addis Ababa University Female Students . Department of Community Health, Addis Ababa University, Addis Ababa, Ethiopia; 2004.

12. Hailemeskel S, Gebre-medhin M: Sexual coercion among female students of Haramaya University in Ethiopia. Harar Bull Health Sci. 2011, 1:124-38.

13. Jewkes R, Abrahams N: The epidemiology of rape and sexual coercion in South Africa: an overview . Soc Sci Med. 2002, 55:1231-44. 10.1016/s0277-9536(01)00242-8

14. Lattey K, Russell M, Brown A: ten years in Ethiopia: what differences did the Millennium Development Goals really make?. (2016). Accessed: July 3, 2021: http://www.maternityworldwide.org/wpcontent/uploads/2016/07/10-Years-in-Ethiopia-Poster-RCOG-June-2016.pdf.

15. Agardh A, Tumwine G, Asamoah BO, Cantor-Graae E: The invisible suffering: sexual coercion, interpersonal violence, and mental health--a cross-sectional study among university students in south-western Uganda. PLoS One. 2012, 7:e51424. 10.1371/journal.pone.0051424

16. Dahlberg LL, Butchart A: State of the science: violence prevention efforts in developing and developed countries. Int J Inj Contr Saf Promot. 2005, 12:93-104. 10.1080/15660970500086239

17. Breiding MJ, Reza A, Gulaid J, et al.: Risk factors associated with sexual violence towards girls in Swaziland . Bull World Health Organ. 2011, 89:203-10. 10.2471/BLT.10.079608

18. Yüce M, Karabekiroğlu K, Yildirim Z, et al.: The psychiatric consequences of child and adolescent sexual abuse. Noro Psikiyatr Ars. 2015, 52:393-9. 10.5152/npa.2015.7472

19. Gelaye B, Arnold D, Williams MA, Goshu M, Berhane Y: Depressive symptoms among female college students experiencing gender-based violence in Awassa, Ethiopia. J Interpers Violence. 2009, 24:464-81. $10.1177 / 0886260508317173$

20. Mohammed BH, Johnston JM, Harwell JI, Yi H, Tsang KW, Haidar JA: Intimate partner violence and 


\section{Cureus}

utilization of maternal health care services in Addis Ababa, Ethiopia. BMC Health Serv Res. 2017, 17:178. 10.1186/s12913-017-2121-7

21. Judith M: Beyond Victims and Villains: Addressing Sexual Violence in the Education Sector . The Panos Institute, London, UK; 2003.

22. Haileye A: Psychopathological correlates of child sexual abuse: the case of female students in Jimma zone, South West Ethiopia. Ethiop J Health Sci. 2013, 23:32-8.

23. Molla T, Cuthbert D: Qualitative inequality: experiences of women in Ethiopian higher education . Gend Educ. 2014, 26:759-75. 10.1080/09540253.2014.970614

24. Muntean N, Kereta W, Mitchell KR: Addressing the sexual and reproductive health needs of young people in Ethiopia: an analysis of the current situation. Afr J Reprod Health. 2015, 19:87-99.

25. Philpart M, Goshu M, Gelaye B, Williams MA, Berhane Y: Prevalence and risk factors of gender-based violence committed by male college students in Awassa, Ethiopia. Violence Vict. 2009, 24:122-36. 10.1891/0886-6708.24.1.122

26. Lwanga SK, Lemeshow S: Sample Size Determination in Health Studies: A Practical Manual . World Health Organization, Geneva, Switzerland; 1991.

27. Lehrer JA, Lehrer VL, Lehrer EL, Oyarzún PB: Prevalence of and risk factors for sexual victimization in college women in Chile. Int Fam Plan Perspect. 2007, 33:168-75. 10.1363/ifpp.33.168.07

28. Meleku M, Sendo EG: Prevalence and factors associated with sexual violence among female students of Hawassa University in Ethiopia. Sci Postprint. 2015, 1:e00047. 10.14340/spp.2015.04A0002

29. Gebreyohannes Y: Prevalence and Factors Related to Gender Based Violence Among Female Students of Higher Learning Institutions in Mekelle town, Tigray, Northern Ethiopia. Department of Community Health, Addis Ababa University, Addis Ababa, Ethiopia; 2007.

30. Abbey A, Zawacki T, Buck PO, Clinton AM, McAuslan P: Alcohol and Sexual Assault. Alcohol Res Health. 2001, 25:43-51. 